\title{
Examining the Early Impact of COVID-19 on Single-Parent TANF Caseloads: a Brief Analysis of New Jersey
}

\author{
Annie S. Lee ${ }^{1}$ (D) David Seith ${ }^{2}$. Jessica L. Roman ${ }^{2}$ - Joanne Taylor ${ }^{3}$. \\ Annette Riordan ${ }^{3} \cdot$ Amman Seehra $^{3} \cdot$ Andrea Hetling $^{2}$
}

Accepted: 18 July 2021 / Published online: 20 September 2021

(c) The Author(s), under exclusive licence to Springer Nature Switzerland AG 2021

\begin{abstract}
Hard economic times often force a greater number of families to turn to public benefits and programs for financial help. These larger safety net caseloads are more diverse than those of strong economic times, including families who are brand-new to the safety net as well as families who, under different economic circumstances, may have needed only short-term assistance. These families may differ from traditional recipients in terms of characteristics and circumstances. To understand how the New Jersey single-parent Temporary Assistance for Needy Families (TANF) caseload changed in response to COVID-19 between April of 2019 and April of 2020, we conducted a two-step cluster analysis that identified six different types of families. Compared to the April 2019 (pre-pandemic) caseload, we found that the number of the TANF participants increased in April 2020 (during the COVID19 pandemic). Interestingly, we also found that the largest proportional increases in the caseload were driven by single jobless adults who are older, have at least a high school education, do not have a disability, and have fewer and older children, while the largest declines were driven by single adults with a job. Taken together, it seems that single adults with relatively better demographic circumstances are having a harder time finding jobs, and so turned to or remained on TANF in April 2020. In response to the pandemic, some, but not all, states have relaxed or temporarily suspended TANF work requirements and time limits. Our findings suggest that such changes in TANF requirements reflect empirical changes in the caseload and merit further attention, particularly in terms of federal and state budget strain.
\end{abstract}

Keywords COVID-19 - TANF participants · Demographic conditions · Economic conditions · Two-step cluster analysis

Annie S. Lee

annie.lee@mail.mcgill.ca

Extended author information available on the last page of the article 
In hard economic times, families who would not ordinarily rely on public benefits or income supports may turn to safety net programs, leading to larger caseloads with a more varied composition. Similarly, those already using public supports may remain on the caseload longer than initially anticipated. The caseload composition of these programs often becomes less, rather than more disadvantaged during such economic downturns, for example, with more married parents and more parents without recent experiences of poverty (Irving, 2011). This paper describes how the composition of the New Jersey Temporary Assistance for Needy Families (TANF) single-parent caseload changed during the initial onset of the COVID-19 pandemic. Findings provide insights on the early impact of the pandemic on safety net utilization and suggest possible directions for continuing trends and policy responses.

COVID-19 began sweeping the globe in early 2020, with the first case of the virus in the USA reported on January 20, 2020, in Washington State (Holshue et al., 2020). The World Health Organization declared COVID-19 a pandemic on March 11, 2020 (World Health Organization, 2020). The White House declared the virus a national emergency soon after on March 13, 2020 (The White House, 2020). Millions of families across the country continue to feel the devastating impact of COVID-19, including economically. An Urban Institute study surveyed nonelderly adults between late March and mid-April 2020 to determine initial effects the pandemic had on employment, income, and ability to fulfill basic needs. Researchers found just over $40 \%$ of respondents reported family members losing jobs or income, or having work hours cut. Approximately one-third of respondents reported being unable to afford payments for basic needs like housing, food, and healthcare. Low-income families experienced financial and material struggles at higher rates (Karpman et al., 2020). Researchers estimate that COVID-19 increased the monthly Supplemental Poverty Measure (SPM) rate by 3 to 7\% each month between March and September, and while the Coronavirus Aid, Relief, and Economic Security (CARES) Act ameliorated this shock for many families, it was less effective for Black, Hispanic, and deep poor families (Parolin et al., 2020). In this context, the SPM is a better measure than the traditional poverty line because it reflects disposable income by taking a wider range of income and expenses into account; counts cohabitating partners, children, and youth as family; benchmarks resources relative to the contemporary costs of food, clothing, shelter, utilities, and other miscellaneous expenditures; and accounts for regional variations in these costs (Fox, 2019).

TANF, one of the core safety net programs in the USA, supports vulnerable groups by providing cash assistance benefits and related work support programs, such as work training and transportation and child care vouchers (Falk, 2014; Hahn, 2018). The federal legislation limits TANF participants to families with dependent children, and each state requires people to meet certain income criteria to be in the program (Blank \& Ruggles, 1996; CBPP, 2021; Falk, 2014; Purtell et al., 2012). People experiencing barriers to engaging in economic activities related to childcare responsibilities or disabilities tend to participate in the program (Hahn, 2018). TANF child-only cases and caretaker relative-child cases are cases in which the adult on the case only receives assistance for the children in their care and not for themselves. Thus, these adults are not required to participate in work activities and are exempt from other program requirements, such as time limits. Even excluding child-only 
cases, TANF caseloads include both unemployed and employed participants (Falk, 2014). Falk and Landers (2020) report that $32.1 \%$ of 2018 TANF cases were families with unemployed adults, $26.7 \%$ were families with an employed adult, and the remaining $41.2 \%$ of the 2018 TANF cases are child-only cases. While employment is common among TANF participants, most are underemployed or working in lowpaying jobs (Falk \& Landers, 2020; Office of Family Assistance, 2012).

Safety net programs may see increased participation due to the severe economic impact of COVID-19. The US Department of Health and Human Services (HHS) released guidance for states on how to use human service programs to serve families during the pandemic in March 2020. Specifically, HHS declared states would not be penalized for failure to meet work participation requirements, but instead would receive exemption relief for cases meeting reasonable cause requirements (HHS, 2020). TANF includes work activity requirements and imposes a lifetime limit on recipients, in addition to general eligibility requirements, for most non-child-only cases and these requirements are particularly critical for single-adult, work-eligible cases (Center on Budget and Policy Priorities [hereafter, CBPP], 2021).

Following the flexibility offered by the federal government, many states have implemented pandemic-related policy changes and waivers in their TANF programs. Several states chose not to include federal COVID-19 relief toward income eligibility requirements or benefits calculations. A few states adjusted income thresholds and benefits calculations overall (Shantz et al., 2020). Some states, like California and Connecticut, temporarily froze TANF time limits, while others continued to process benefit renewals for families who reached their time limit (Burnside, 2020). An Urban Institute study found 12 out of 19 participating states used good cause exemptions to waive work requirements for all recipients while two states used the exemptions to waive work requirements for targeted groups of recipients (Shantz et al., 2020). States waived sanction policies related to work requirements as well (Burnside, 2020). As Americans lose jobs, see decreases in wages, and struggle to afford basic needs during the pandemic, some may turn to safety net programs like TANF to provide for their families. In fact, Pavetti (2020) reported, "In California, Vermont, and Washington applications ... more than doubled" comparing caseload numbers from the beginning of March 2020 to the start of April 2020 (np). As such, TANF caseloads from March 2020 on are likely to look different than caseloads prior to the pandemic.

\section{TANF During the Great Recession}

Important to our analysis is understanding how the TANF program functioned under other economic downturns. Thus, we turn to the Great Recession which lasted from December 2007 to June 2009 (Haskins et al., 2014). The Great Recession was marked with increased unemployment throughout the USA, leaving families financially vulnerable. Several studies reported modest increases in TANF participation rates during the Recession (Haskins et al., 2014; Moffitt, 2013; Pilkauskas et al., 2012). However, Moffitt (2013) and Haskins and colleagues (2014) found that while 
the social safety net overall supported families during the Great Recession, TANF's performance was inadequate.

Part of the program's weak performance may have been related to expenditure distribution across safety net programs. The bulk of expenditures went to social insurance programs like unemployment insurance rather than means-tested programs like TANF. And among means-tested programs, TANF expenditures were much lower than programs like the Supplemental Nutrition Assistance Program (SNAP) and Medicaid. As result, families that are more likely to rely on TANF, like single-parent families, may not have been buffered by the safety net as effectively as hoped or expected during the Great Recession (Moffitt, 2013). Haskins and colleagues (2014) conclude in their study of TANF responsiveness during the Great Recession that TANF was one of the least responsive safety net programs in terms of providing benefits to more people as unemployment rose. Although the number of TANF cases held constant or increased slightly among the states, TANF benefits reached an extremely low proportion of those in poverty (Haskins et al., 2014). Specifically, “...the percentage of poor people receiving TANF reached historic lows during the recession, precisely the time a safety net program would be expected to cover more of the poor" (Haskins et al., 2014, p. 45). With a small uptick in TANF participation during the Great Recession, state spending on the program increased. The American Recovery and Reinvestment Act included federal reimbursement for states' increased cash assistance and subsidized job program expenditures, in attempting to buttress the economy (Shantz et al., 2020). Overall, the impact of the Great Recession on the TANF program, both in terms of family benefits and state costs, indicates that the program was not as responsive or accessible as expected.

\section{TANF During COVID-19}

TANF during COVID-19 is unique, because the program must respond to a global pandemic, and related stay-at-home orders, in addition to an economic downturn. Dissimilar to TANF during the Great Recession, several states have suspended or relaxed their program's work requirements during the pandemic (Burnside, 2020; Moffitt, 2013; Shantz et al., 2020). Moreover, COVID-19 has had a particularly negative impact on traditionally vulnerable populations, including those who are socioeconomically disadvantaged and those with disabilities (Shadmi et al., 2020). Many vulnerable populations fell into unemployment after the pandemic started, which increased their dependency on the safety net program (Hembre, 2020; Saloner et al., 2020; Shantz et al., 2020). Several states reported that the total number of TANF participants increased significantly shortly after the pandemic started (Hembre, 2020; Saloner et al., 2020; Shantz et al., 2020). Hembre (2020) also found that there is a positive relationship between the unemployment rate and the number of TANF participants. The unemployment rate in New Jersey was 3.3\% in April 2019 and it drastically increased up to $16.6 \%$ in April 2020, which is the unprecedently high rate after the Great Recession (US Bureau of Labor Statistics). The number of families in the TANF program also increased significantly in April 2020 responding to the pandemic; the total number of the families in NJ TANF program in April 2019 was 
10,830 and it increased up to 11,235 in April 2020 (NJ Department of Human Services, 2020). ${ }^{1}$ Several researchers have focused on how the pandemic has aggravated low-income people's economic struggles and dependency on public supports, but they have not yet explored how its negative impact differs across various types of families. Our research tried to fill these research gaps by exploring how the TANF caseload has changed, not just in size, but in terms of case characteristics and the proportion of different TANF participant groups, between April 2019 and 2020.

\section{Study State: New Jersey}

This inquiry into the changes in the TANF caseload during the early part of the COVID-19 pandemic is especially critical for the state of New Jersey, which was hit hard at the pandemic's start. Findings provide insights into changes in the composition of the TANF caseload and the ways families are different from the previous year. Given the timing of the pandemic in New Jersey, our study state also serves as a case for the other states that experienced shutdowns and economic impacts later in the summer. New Jersey Governor Phil Murphy declared a state of emergency in response to COVID-19 on March 9, 2020 (State of New Jersey, 2020). By April 24, 2020, approximately one in five New Jersey workers applied for unemployment insurance and the state reported nearly 100,000 positive COVID-19 cases and over 5000 deaths (Dipaolo, 2020). In response to the pandemic and Governor Murphy's executive order declaring a state of emergency, the New Jersey Department of Human Services Division of Family Development issued a directive suspending TANF work requirements, redeterminations, and sanctions across the state beginning on March 16, 2020 (Johnson, 2020). County offices also allowed for caseworkers to schedule application interviews over the telephone instead of in-person. Due to COVID-19's widespread, negative economic impact, and related changes in TANF regulations in the early spring, we hypothesize that characteristics of TANF recipients from March 2020 may look different than prior to the start of the pandemic.

\section{Data and Methods}

To assess the possible early impact of the COVID-19 pandemic and policy changes on the composition of TANF caseloads, we used April 2019 and April 2020 data from New Jersey TANF Data Reports (TDR), which provides detailed information on TANF participants' socioeconomic conditions. We excluded both child-only cases and two-parent cases from the analysis because those cases are subject to different regulations and work requirements, and are less likely to be affected by the economic and policy changes related to the pandemic. The sample is thus restricted to single-adult recipient cases in this analysis. Furthermore, the

\footnotetext{
1 The total number of the case TANF program includes all types of the families (including the child-only cases and two-parent families) and all types of funded cases (state-funded cases, State Maintenance of Effort (MOE) dollars funded cases and federal-funded cases) (WorkFirst NJ, 2017).
} 
New Jersey TDR includes data on TANF recipients that are funded by federal TANF dollars, and thus does not include cases that are in separate state-funded programs. As in other states, New Jersey attempts to maximize the number of families who most closely meet federal eligibility and participation guidelines, by reporting those families to the federal government in the TDR, while funding other eligible families with lower work participation rates through separate state funds. By focusing on federally funded cases, our analysis is intended to be more generalizable to TANF cases in other states.

The final analytical dataset includes 4574 single parent recipient cases in April 2019 and 5529 cases in April 2020. We used the cluster analysis model to compare how the proportion of participant groups with similar characteristics changed between April 2019 and 2020. In other words, did the various cluster groups increase or decrease in size between the two time periods? We use the pooled dataset for the analysis. Some TANF participants are observed in both the April 2019 and 2020 datasets, and we treated them as separate observations. We conducted the same cluster analysis without including these observations and found a similar pattern. We concluded that these participants do not change the overall trend.

Five demographic variables and two economic variables were used in our analysis. We used recipient age, high school education (measured dichotomously as possessing at least a high school diploma or GED versus less than high school education), disability (exempt due to medical disability), family size, and presence of children under 5 years old for the demographic variables. We used monthly TANF countable net income and employment status for the economic variables. After conducting the cluster analysis, we examined the average number of months on TANF, or length of stay, for participants in each cluster group. We used the cumulative number of months participants have used toward their TANF lifetime federal limit, also known as the TANF clock to estimate this.

Most of the existing research on safety net programs use traditional cluster analysis methods, such as a $k$-means cluster analysis and hierarchical cluster analysis (Chambers \& Potter, 2008; Slack et al., 2014; Snarr et al., 2012). The limitation of the traditional cluster analysis methods is that it does not allow for use of both categorial and continuous variables in the same model. We were unable to use the traditional cluster analysis methods as we used mixed variables. Instead, we used a two-step cluster analysis using the SPSS program, which is a relatively new approach in TANF research. In the two-step cluster analysis, data are first clustered into sub-cluster groups. Then, sub-clusters are once again categorized into a certain number of cluster groups. The appropriate number of cluster groups is determined by Bayesian information criterion (or Akaike information criterion) and distance change between clusters (SPSS two-step cluster technical report). We also utilized a Partitioning Around Medoids (PAM) cluster analysis model using the R program as a check for the robustness of these results. Similar to two-step cluster analysis, PAM cluster analysis model could be utilized for mixed variables and the appropriate number of cluster groups is determined by the silhouette coefficient. We confirmed 
Table 1 Descriptive statistics for TANF participants

\begin{tabular}{|c|c|c|c|c|}
\hline & \multicolumn{2}{|l|}{ April 2019} & \multicolumn{2}{|l|}{ April 2020} \\
\hline & $M(S D)$ & $\%$ & $M(S D)$ & $\%$ \\
\hline Age & $31.29(8.33)$ & - & $31.77(8.25)$ & - \\
\hline With high school diploma or GED & - & 66.29 & - & 66.38 \\
\hline With a known disability & - & 7.08 & - & 5.77 \\
\hline Family size & $2.93(1.12)$ & - & $2.94(1.11)$ & - \\
\hline With child under 5 & - & 62.16 & - & 60.44 \\
\hline Monthly income & $168.33(485.00)$ & - & $107.11(384.01)$ & - \\
\hline Employed & & 13.84 & - & 9.75 \\
\hline Total & 4574 & & 5529 & \\
\hline
\end{tabular}

Standard error in parentheses

that PAM analysis results showed similar patterns to the two-step cluster analysis result. $^{2}$

\section{Results}

The TANF caseload in New Jersey was larger in April 2020, after the onset of COVID-19, compared to April 2019, one year earlier. There were 4574 single-parent adult cases in April 2019 and 5529 cases in April 2020. The total number of cases in 2020 was $20.88 \%$ higher (+955 cases) than in 2019 (see, Table 1). The demographic circumstances of TANF participants in April 2019 and April 2020 were, on average, quite similar or slightly less challenged to engage in economic activities in April 2020; specifically, the participants in April 2020 are slightly older, and a larger share of participants has high school diploma, without a preschool-aged child and without a disability. However, the economic conditions of TANF participants in April 2020 were substantially poorer than the participants in April 2019. Nearly 14\% (13.84\%) of the participants were employed in April 2019, but only $9.75 \%$ of the participants were employed in April 2020. The average monthly TANF countable net income for participants in April 2019 was \$168.33 and \$107.11 for participants in April 2020.

\section{Cluster Groups Within the TANF Caseload}

As portrayed in Table 2, the two-step cluster analysis revealed six different types of families, including single parents with:

- Group 1: Preschool or younger children, a larger family, and less than a high school education (1796 cases, $17.78 \%$ of the total cases)

\footnotetext{
${ }^{2}$ Our analysis result using the PAM model is available upon request from the contact author.
} 


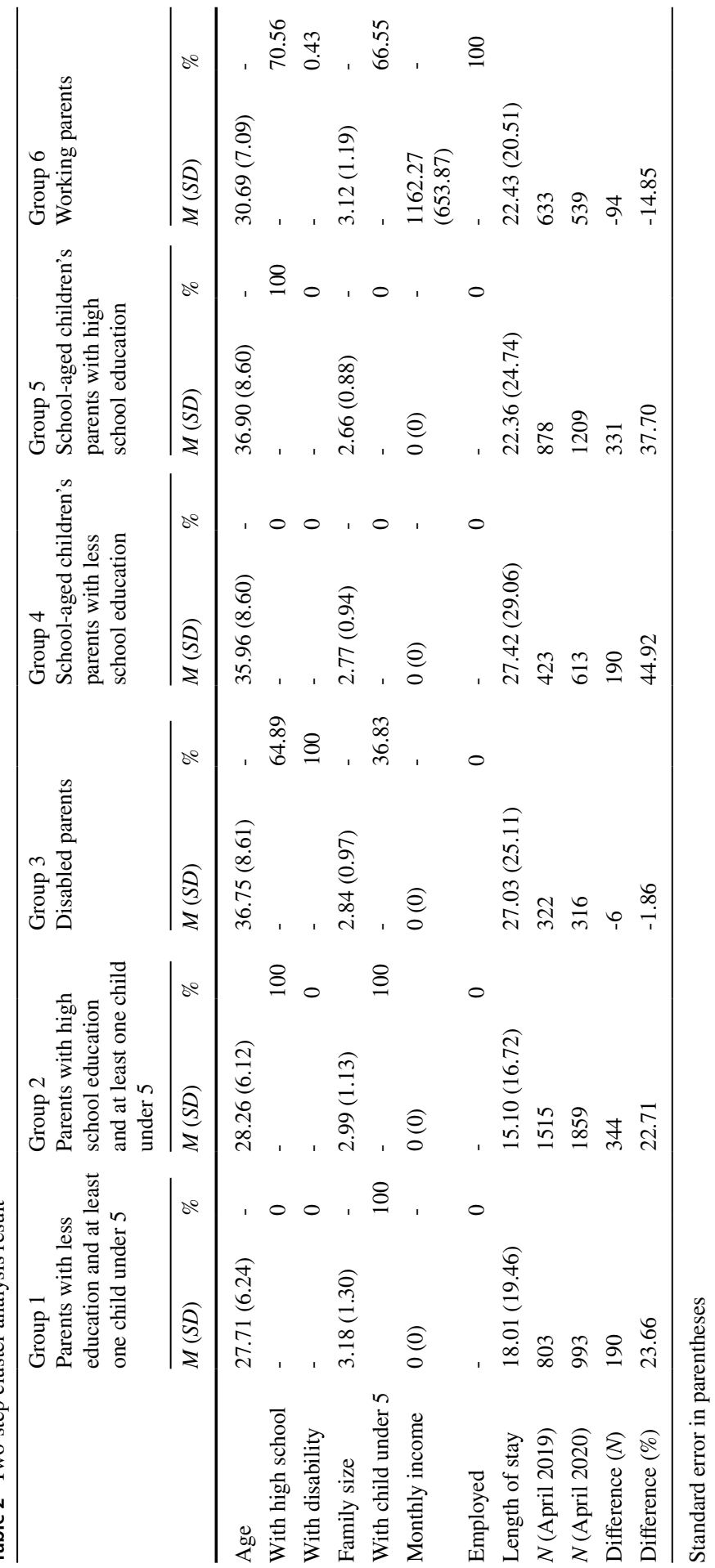


- Group 2: Preschool or younger children, a larger family, and a high school education ( 3374 cases, $33.40 \%$ of the total cases)

- Group 3: A known disability (638 cases, $6.31 \%$ of the total cases)

- Group 4: School-aged children, a smaller family, and less than a high school education ( 1036 cases, $10.25 \%$ of the total cases)

- Group 5: School-aged children, a smaller family, and a high school education (2087 cases, $20.66 \%$ of the total cases)

- Group 6: Formal employment earnings (1172 cases, $11.60 \%$ of the total cases)

Columns 1 and 2 in Table 2 present the profiles of our first two cluster groups: group 1, which included young, large families with less than a high school education, and group 2, which included young families with high school diplomas or GEDs. The demographic conditions of TANF participants in cluster group 1 were similar to participants in cluster group 2, except for the high school diploma; participants in cluster groups 1 and 2 are relatively younger (average 27.71 years old for group 1 and 28.26 years old for group 2), without a disability, with relatively large family size (average 3.18 for group 1 and 2.99 for group 2) and with children under 5 years old. Considering the groups' previous TANF receipt, we found that the average number of months of prior TANF receipt for participants in these two cluster groups was relatively shorter than other groups (18.01 months for cluster group 1 and 15.10 months for cluster group 2). The average months of receipt for cluster group 2 was shorter than all other cluster groups. This implies that there is a relatively larger share of short-term participants in these groups.

The distinctive characteristic of TANF participants in the cluster group 3 was their disability status; all participants in this group had a known disability in contrast to 0 or close to $0 \%$ in the other five clusters. Their average age was relatively older (36.75), 64.89\% of the participants had a high school diploma, the average family size was 2.84 , and $36.83 \%$ of the participants had children under 5 years old. The average length of stay was 27.03 months (more than 2 years), considerably longer than other cluster groups.

Participants in cluster groups 4 and 5 were less challenged and had fewer barriers to engaging in economic activities than the participants in cluster groups 1 and 2; TANF participants were older (average 35.96 for group 4 and 36.90 for group 5), without a disability, with smaller family size (average 2.77 for group 4 and 2.66 for group 5), and without children under 5 years old. Demographic conditions of cluster groups 4 and 5 were quite similar to each other except for the high school diploma; the TANF participants in cluster group 4 did not have a high school diploma, but participants in group 5 had a high school diploma. The average length of stay for TANF participants in these two cluster groups was relatively longer than other groups (27.42 months for cluster group 4 and 22.36 months for cluster group 5).

Among the six cluster groups, participants in cluster group 6, employed parents, had relatively better economic conditions than the participants in the other five groups (cluster groups 1 to 5). The average countable earned income for TANF participants at the time of application in cluster group 6 was $\$ 1162.27$, but it was $\$ 0$ for participants in cluster groups 1 to 5 . Moreover, all participants in cluster group 6 
were employed, while no participants in groups 1 to 5 were employed. The average age of TANF participants in cluster group 6 was 30.69 years old, more than $70 \%$ of participants had a high school diploma, $0.43 \%$ of participants had a disability, average family size was 3.12 , and $66.55 \%$ of the participants had children under 5 years old.

\section{Changes in the Cluster Groups over Time}

We next examined how, if at all, the number of TANF cases in each cluster group changed from April 2019 (pre-pandemic) to one year later, April 2020 (during the COVID-19 pandemic). Two of the six groups decreased in size between our study months. The largest decrease was seen in group 6, employed parents; the total number of TANF cases in cluster group 6 was smaller in April 2020 than the 2019 April $(-14.85 \%)$ (see Table 2). This implies that there were fewer participants with relatively good economic conditions in April 2020 than in April 2019. The total number of TANF cases in cluster group 3, participants with a disability, was also slightly smaller in April 2020 than in April 2019 (-1.86\%).

In contrast, the total number of TANF cases in cluster groups 1, 2, 4, and 5 were higher in April 2020 than in April 2019. Between April 2019 and 2020, cluster group 2 experienced the largest increase ( +334 cases), with cluster group 5 closely following (+331 cases). Participants in both cluster groups 2 and 5 had a high school diploma. This suggests that single adults with at least the minimum education required of the labor market were having a harder time finding jobs, and may have turned to TANF or remained on TANF in April 2020. Although cluster group 2 experienced the largest increase in terms of raw numbers, the proportional difference was not large; 33.12\% of the total TANF cases in April 2019 were in cluster group 2 compared to $33.62 \%$ in April 2020. The largest number of TANF participants were in cluster group 2 in both April 2019 and 2020.

Proportionally, cluster group 4 experienced the largest increase $(+44.92 \%)$. About $9.25 \%$ of the total TANF cases in April 2019 were in cluster group 4, but $11.09 \%$ of total TANF cases in April 2020 were in cluster group 4. TANF cases in cluster group $5(+37.70 \%)$ followed next. Approximately $19.20 \%$ of the total TANF cases in April 2019 were in cluster group 5, but $21.87 \%$ of the total TANF cases in April 2020 were in cluster group 5. Compared to the participants in cluster groups 1 and 2, participants in cluster groups 4 and 5 were relatively older, without disability, with smaller family size, and without a child under 5 years old. This implies that the proportion of TANF participants with better demographic conditions, but poor economic conditions, increased in April 2020. This may be partly due to COVID-19, which jeopardized the incomes of families who otherwise might not turn to TANF and decreased the opportunities for employment among current TANF participants.

\section{Discussion and Conclusions}

We conducted a two-step cluster analysis using the April 2019 and 2020 data from New Jersey TANF Data Reports (TDR) to examine the early impact of COVID-19. 
This two-step cluster analysis identified six different types of families. Only one cluster group captured participants who were employed, while participants in the other five cluster groups were all unemployed and had no average monthly countable earned income at application. We found that the largest declines in the TANF caseloads were attributable to those who had a job. The negative economic effects of the pandemic among TANF participants were quite noticeable in our analysis.

We found that the largest proportional increase in the caseloads was caused by unemployed families with fewer challenges to engage in the economic activities. TANF participants in these types of families were older, without a disability, with a smaller family size, and without a preschool-aged child (less challenging demographic conditions), but were unemployed and earned zero monthly income. This implies that many TANF participants who would normally tend to have better economic conditions fell into a worse economic situation in April 2020. They may have experienced difficulties finding a job and turned to TANF. Moreover, in terms of raw numbers, April 2020 also had an increased number of participants with a high school diploma, another signal that the pandemic may be leading to an increase in representation of more traditionally advantaged families in the cash assistance system.

Our findings are tempered by three limitations. First, we investigated only the April 2020 caseload, which captured just the early phase of the pandemic. To understand the full picture of COVID-19, we need to investigate TANF participants in subsequent periods. Second, the dataset we used in the analysis only included TANF participants funded by federal TANF dollars. TANF participants in this dataset could be different from the TANF participants who are supported by state TANF or MOE funds. States, in response to federal incentives, tend to move cases with more challenging barriers to employment to their state programs in an effort to meet federal work participation rate (WPR) benchmarks and avoid penalties. Thus, TANF participants funded by federal TANF dollars may have relatively better socioeconomic conditions and have higher possibility to meet work requirements than the participants in the state programs. An examination of the state-funded caseload might yield different results. Third, time is a critical variable that merits further research. While a comparison of changes in the caseload stock at two points in time provides a timely assessment of how its composition has changed, analyses of the longitudinal entry and exit flows often provides a more nuanced understanding of the change process and whether administrators should focus efforts on intake, ongoing, or exit services. Because we pool the two cross sections in the cluster analysis, including some participants observed at both points in time, our analysis is subject to confounding of elapsed time, in that some of our measures, such as age of the youngest child, education, disability exemption, employment, and even household composition, are time-varying.

Our research is meaningful in the sense that we captured the early impact of COVID-19 on TANF participants. Our findings can aid policymakers and TANF administrators in anticipating and understanding the needs and circumstances of TANF families during economic downturns. Our findings also highlight how the safety net (including the TANF program) responded to the negative social change caused by the pandemic. The welfare reforms and minimum wage and 
earned income tax credit (EITC) expansions of the Clinton administration shifted America's primary cash safety net from a countercyclical entitlement (Aid to Families with Dependent Children, or AFDC) to a procyclical refundable tax credit (the EITC) (Bernstein, 2003; Schott, 2017; Weaver, 2002). As a block grant with fixed, inflation-eroded federal reimbursement, and widely varying state eligibility and benefit thresholds, TANF is much less effective than its predecessor, AFDC, or its sibling program, the Supplemental Nutrition Assistance Program (SNAP), as an automatic fiscal stabilizer or safety net (Schott, 2017; Weaver, 2002). Relatively small increases in the TANF caseload during the Great Recession are a signal of this structural challenge.

Our findings are cause for some optimism in terms of the functioning of the TANF program early in the COVID-19 pandemic. While our results indicate increased economic needs among a larger group of low-income families, we simultaneously see a strong role of the TANF program in meeting those needs. More and new families are relying on TANF in hard times like these, despite less challenging family demographic conditions (older, without disability, smaller family size, and without a pre-school aged child) and sometimes relatively higher education. Our findings indicate that early pandemic-related waivers and practice flexibility resulted in a more responsive program. However, increases in caseload size, particularly if sustained over time and during a pandemic, will likely cause financial burdens on states. And indeed, the number of TANF cases quickly and drastically increased at the start of the pandemic (Pavetti, 2020). Our findings on cluster groups also indicate that the ability of states to meet their federally mandated WPR will be challenging at best. States will struggle to help participants find employment with employment less common and increases among work-ready participants who likely do not qualify for hardship or disability waivers. If the safety net is to hold, Congressional actions to increase benefits to families and reimbursements to states will most likely be necessary.

In addition, understanding who is turning to TANF during the pandemic is imperative to the program's service provision. One of the key findings in our research is that families who rely on the safety net program during economic recessions are different from the families in other times. In our sample, a larger share of the TANF participants in April 2020 has arguably less challenging demographic conditions (a high school diploma, older children, older, and no disability), but were unsuccessful in finding employment. Families who would normally engage in economic activities may have experienced pandemic-related layoffs or unsuccessful job applications during this time of high unemployment and thus chose to enter the TANF program. Similarly, families, who might have needed assistance for only a short time in a stronger economy, might have had difficulty in finding a job. These scenarios imply that some current TANF participants may have a higher possibility of returning to work activities when the economy stabilizes. This is quite different from TANF participants in other times, where a larger share of participants' labor participation is deterred by personal circumstances (such as having a child under two years old or with a disability), not mainly deterred by macro-level economic situations. Therefore, the policylevel approach toward TANF participants during a severe economic downturn 
should be differentiated from the other times and should include work activity waivers and good cause exemptions for meeting requirements that are mainly dependent on economic opportunities.

Funding This research was supported in part by funding from the New Jersey Department of Human Services, Division of Family Development, and the US Department of Health and Human Services, Administration for Children and Families, Office of Planning, Research, and Evaluation.

\section{Declarations}

Disclaimer The views and opinions expressed in this article are those of the authors and do not necessarily reflect the official policy or position of the funders.

\section{References}

Bernstein, J. (2003). Our pro-cyclical safety net fails to catch vulnerable families in recession. Economic Policy Institute. Retrieved November 15, 2020, https://www.epi.org/publication/webfeatures_ snapshots_archive_11062002/

Blank, R. M., \& Ruggles, P. (1996). When do women use aid to families with dependent children and food stamps? Journal of Human Resources, 31(1), 57-89. https://doi.org/10.2307/146043

Burnside, A. (2020). During COVID-19, states should continue waiving TANF work requirements and time limits. The Center for Law and Social Policy. Retrieved November 17, 2020, from https:// www.clasp.org/blog/during-covid-19-states-should-continue-waiving-tanf-work-requirementsand-time-limits

Center on Budget and Policy Priorities. (2021). Policy basics: Temporary assistance to needy families. Retrieved November 15, 2020, from https://www.cbpp.org/sites/default/files/atoms/files/722-10tanf2.pdf

Chambers, R. M., \& Potter, C. C. (2008). The match between family needs and services for highrisk neglecting families. Journal of Public Child Welfare, 2(2), 229-252. https://doi.org/10.1080/ 15548730802312750

Dipaolo, L. (2020). Friday facts and figures: April 24, 2020. New Jersey Policy Perspective. Retrieved November 16, 2020, from https://www.njpp.org/publications/friday-facts-and-figures/fridayfacts-and-figures-april-24-2020/

Falk, G. (2014). Temporary Assistance for Needy Families (TANF): Eligibility and benefit amounts in state TANF cash assistance programs. Congressional Research Service Washington, DC. Retrieved November 15, 2020, from https://www.cbpp.org/research/family-income-support/ temporary-assistance-for-needy-families

Falk, G., \& Landers, P. A. (2020). The Temporary Assistance for Needy Families (TANF) block grant: Responses to frequently asked questions. Retrieved November 15, 2020, https://crsreports.congress. gov/product/pdf/RL/RL32760/194

Fox, L. (2019). The supplemental poverty measure 2018. Current Population Reports. Retrieved November 15, 2020, from https://www.census.gov/library/publications/2019/demo/p60-268.html

Hahn, H. (2018). Work requirements in safety net programs. Urban Institute. Retrieved November 16, 2020, from https://www.urban.org/sites/default/files/publication/98086/work_requirements_in_ safety_net_programs.pdf

Haskins, R., Albert, V., \& Howard, K. (2014). The responsiveness of the temporary assistance for needy families program during the great recession. The Brookings Institution. Retrieved November 15, 2020, from https://www.brookings.edu/research/the-responsiveness-of-the-temporaryassistance-for-needy-families-program-during-the-great-recession/

Hembre, E. (2020). Examining the social safety net response to the COVID-19 pandemic. Available at SSRN 3693339. https://doi.org/10.2139/ssrn.3693339 
Holshue, M. L., DeBolt, C., Lindquist, S., Lofy, K. H., Wiesman, J., Bruce, H., Spitters, C., Ericson, K., Wilkerson, S., \& Tural, A. (2020). First case of 2019 novel coronavirus in the United States. New England Journal of Medicine. https://doi.org/10.1056/NEJMoa2001191

Johnson, N. (2020). Division of family development program instruction. New Jersey Department of Human Services, Division of Family Development. Retrieved November 15, 2020, from https:// carefinders.org/wp-content/uploads/2020/04/Welfare-NJ-SNAP-requirements-for-COVID-19Preparedness.pdf

Irving, S. K. (2011). Comparing program participation of TANF and non-TANF families before and during a time of recession. US Department of Commerce, Economics and Statistics Administration, U.S. Census Bureau. Retrieved November 15, 2020, from https://www2.census.gov/library/ publications/2011/demo/p70-127.pdf

Karpman, M., Zuckerman, S., Gonzalez, D., \& Kenney, G. M. (2020). The COVID-19 pandemic is straining families' abilities to afford basic needs. Urban Institute. Retrieved November 15, 2020, from https://www.urban.org/research/publication/covid-19-pandemic-straining-familiesabilities-afford-basic-needs

Moffitt, R. A. (2013). The Great Recession and the social safety net. The Annals of the American Academy of Political and Social Science, 650(1), 143-166. https://doi.org/10.1177/0002716213499532

NJ Department of Human Services. (2020). Current program statistics. State of New Jersey, Department of Human Services, Division of Family Development. Retrieved November 15, 2020, from https:// www.state.nj.us/humanservices/dfd/news/cps_may20.pdf

Office of Family Assistance. (2012). Characteristics and financial circumstances of TANF Recipients, Fiscal Year 2010. Retrieved November 15, 2020, from https://www.acf.hhs.gov/ofa/data/chara cteristics-and-financial-circumstances-tanf-recipients-fiscal-year-2010

Parolin, Z., Curran, M., Matsudaira, J., Waldfogel, J., \& Wimer, C. (2020). Monthly poverty rates in the United States during the COVID-19 pandemic, Poverty and social policy working paper, Center on poverty \& social policy. Retrieved November 15, 2020, from, https://static1.squarespace.com/ static/5743308460b5e922a25a6dc7/t/5f87c59e4cd0011fabd38973/1602733471158/COVID-Proje cting-Poverty-Monthly-CPSP-2020.pdf

Pavetti, L. (2020). With applications soaring, TANF needs more funds, new rules. Center on Budget and Policy Priorities. Retrieved November 15, 2020, from https:/www.cbpp.org/blog/with-applicationssoaring-tanf-needs-more-funds-new-rules

Pilkauskas, N. V., Currie, J. M., \& Garfinkel, I. (2012). The great recession, public transfers, and material hardship. Social Service Review, 86(3), 401-427. https://doi.org/10.1086/667993.

Purtell, K. M., Gershoff, E. T., \& Aber, J. L. (2012). Low income families' utilization of the Federal "Safety Net": Individual and state-level predictors of TANF and Food Stamp receipt. Children and Youth Services Review, 34(4), 713-724. https://doi.org/10.1016/j.childyouth.2011.12.016

Saloner, B., Gollust, S. E., Planalp, C., \& Blewett, L. A. (2020). Access and enrollment in safety net programs in the wake of COVID-19: A national cross-sectional survey. PLoS ONE, 15(10), e0240080. https://doi.org/10.1371/journal.pone.0240080

Schott, L. (2017). Lessons from TANF: Block-Granting a Safety-Net Program has significantly reduced its effectiveness. Center on Budget and Policy Priorities. Retrieved November 16, 2020, https://www.cbpp.org/research/family-income-support/lessons-from-tanf-block-grantinga-safety-net-program-has

Shadmi, E., Chen, Y., Dourado, I., Faran-Perach, I., Furler, J., Hangoma, P., Hanvoravongchai, P., Obando, C., Petrosyan, V., \& Rao, K. D. (2020). Health equity and COVID-19: Global perspectives. International Journal for Equity in Health, 19(1), 1-16. https://doi.org/10.1186/ s12939-020-01218-z

Shantz, K., Hahn, H., Nelson, M., Lyons, M., \& Flagg, A. (2020). Changes in state TANF policies in response to the COVID-19 pandemic. Urban Institute. Retrieved November 17, 2020, from https:// www.urban.org/research/publication/changes-state-tanf-policies-response-covid-19-pandemic

Slack, K. S., Kim, B., Yang, M.-Y., \& Berger, L. M. (2014). The economic safety net for low-income families with children. Children and Youth Services Review, 46, 213-219. https://doi.org/10. 1016/j.childyouth.2014.08.008

Snarr, H. W., Friesner, D., \& Underwood, D. A. (2012). Evaluating evolutionary changes in state TANF policies. Applied Economics Letters, 19(17), 1753-1758. https://doi.org/10.1080/13504851.2011. 650326 
State of New Jersey. (2020). Governor Murphy declares state of emergency, public health emergency to strengthen state preparedness to contain the spread of COVID-19. Retrieved November 16, 2020, from https://www.nj.gov/governor/news/news/562020/20200309b.shtml

The White House. (2020). Proclamation on declaring a national emergency concerning the novel coronavirus disease (COVID-19) outbreak. Retrieved November 16, 2020, from https://trumpwhitehouse.archives. gov/presidential-actions/proclamation-declaring-national-emergency-concerning-novel-coronavirusdisease-covid-19-outbreak/

US Department of Health and Human Services. (2020). TANF-ACF-PI-2020-01 (questions and answers about TANF and the coronavirus disease 2019 (COVID-19) pandemic). Retrieved November 16, 2020, from https:/www.acf.hhs.gov/ofa/policy-guidance/tanf-acf-pi-2020-01questions-and-answers-about-tanf-and-coronavirus-disease

Weaver, R. K. (2002). The structure of the TANF Block Grant. Brookings. Retrieved November 15, 2020, from https://www.brookings.edu/research/the-structure-of-the-tanf-block-grant/

WorkFirst NJ. (2017). New Jersey State Plan for Temporary Assistance for Needy Families (TANF). Retrieved November 16, 2020, from https:/www.state.nj.us/humanservices/dfd/programs/ workfirstnj/njtanf_ffy_18-20.pdf

World Health Organization. (2020). WHO Director-General's opening remarks at the media briefing on COVID-19. Retrieved November 16, 2020, from https://www.who.int/director-general/speeches/ detail/who-director-general-s-opening-remarks-at-the-media-briefing-on-covid-19---11-march-2020

Publisher's Note Springer Nature remains neutral with regard to jurisdictional claims in published maps and institutional affiliations.

\section{Authors and Affiliations}

\section{Annie S. Lee ${ }^{1}$ D David Seith ${ }^{2}$. Jessica L. Roman ${ }^{2}$ - Joanne Taylor ${ }^{3}$. Annette Riordan $^{3} \cdot$ Amman Seehra $^{3} \cdot$ Andrea Hetling $^{2}$}

David Seith

david.seith@ejb.rutgers.edu

Jessica L. Roman

jessica.roman@rutgers.edu

Joanne Taylor

joanne.m.taylor@dhs.nj.gov

Annette Riordan

annette.riordan@dhs.nj.gov

Amman Seehra

amman.seehra@dhs.nj.gov

Andrea Hetling

ahetling@ejb.rutgers.edu

1 Department of Geography, McGill University, 805 Sherbrooke Street West, Montreal, Quebec H3A 0B9, Canada

2 Bloustein School of Planning and Public Policy, Rutgers University - New Brunswick, 33

Livingston Avenue, New Brunswick, NJ 08901, USA

3 Department of Human Services, Division of Family Development, Trenton, NJ 08625-0716, USA 